Consumer Knowledge and Understanding of Consumer Credit

\begin{abstract}
Much has recently been written about the desirability of restrictive usury laws. While low maximum rates may prevent excessive charges to some, they also limit the ability of high-risk persons to borrow. Therefore, if consumers have a sufficient understanding of the credit market to realize what they are paying for and how much they are paying when they borrow, a case can be made against low maximum finance rates.

This article reports on a nationwide study designed to measure consumer knowledge and understanding of consumer credit. The results are that while consumers can generally rank lenders correctly in terms of cost, there are serious gaps in their knowledge of the credit market. Education and income are the key determinants of knowledge and understanding of consumer credit.
\end{abstract}

Much of the recent attention which has been paid to consumer credit has focused around the maximum allowable rates of interest on consumer loans. Legislation in several states has recently lowered allowable rate ceilings on consumer credit substantially, a few to as little as 10 percent.

Opposing these restrictions on interest rates, aside from the lenders whose vested interests are hurt by such restrictions, are many economists who argue as Paul Samuelson does, that

"setting too low ceilings on small loan interest rates will result in drying up legitimate funds to the poor who need it most and will send them into the hands of illegal loan sharks. History is repleat with cases where loan sharks have lobbied in legislatures for unrealistic maximum rates knowing that such meaningless ceilings would permit them to charge much higher rates" [10]

Implicit in the arguments of economists opposing restrictions on maximum interest rates are several assumptions that are so basically imbedded within the structure of microeconomic theory that they are seldom explicitly considered. Two in particular, however, appear worthy of some explicit consideration. The first underlying assumption is that the consumer who contracts for installment debt actually delib-

Lewis Mandell is study director, Economic Behavior Program, Survey Research Center, Institute for Social Research, The University of Michigan, Ann Arbor, Michigan. 
erates on the debt transaction per se, either separately or as part of a joint decision. A second assumption is that of perfect knowledge and understanding of consumer credit or that the consumer realizes the importance of having such knowledge and knows how to seek the information that he needs in order to make efficient choices in the market. ${ }^{1}$

If both of these criteria are met, unrestricted interest rates should function well. ${ }^{2}$ Let us consider the market behavior of a consumer who meets these criteria and who wants to buy a new refrigerator for which he is unwilling or unable to pay cash. He will first shop around and locate the best buy on a refrigerator and then, resisting the arguments of the merchant to take his credit there, he will shop around for the lowest cost lender. This consumer, of course, realizes that loans may vary by down-payment, monthly dollar amount and total maturity so he uses the annual percent rate of interest as the common denominator to get the lowest cost loan. This consumer also realizes that as a result of certain factors, perhaps the instability of his income for example, he is not the best possible consumer credit risk. However, since he owns his own home-let us assume- - he isn't the worst credit risk either. He knows that there are a number of lenders ranging from, say, the bank that gives credit to the best risks at 8 percent to, say, the finance company which gives credit to almost all comers at 36 percent and he realizes that he fits somewhere in between. Our model consumer probably has a good notion of a range of interest in which he will be able to get a loan, so he works down the list within a relevant range until he finds a lender who will loan him the money at the lowest possible rate of interest consistent with his other needs.

If this pattern of market behavior is characteristic of borrowers, a very good case can be made for unlimited interest rates. There is some evidence, however, that indicates that many, if not most consumers, do

1 The assumption of perfect knowledge is one of the necessary assumptions underlying the state of pure competition which is needed to maximize household satisfaction from its total consumption of all goods. That assumption, however, may be relaxed if it can be assumed that "each buyer ... possesses that knowledge of the relevant data that he is bound to acquire as he implements and revises his plans. Thus a household may make its initial purchase plan on the basis of certain expectations about the capability of certain products to satisfy its wants: as it actually buys and consumes these products it will gain some clearer notions about the satisfactions they provide, and its purchase plan for the subsequent period will be laid on the basis of these" [9, p. 264].

2 This statement assumes, of course, that additional (non-interest-related) barriers to entry do not create monopoly elements within the consumer loan market. For a discussion of the effects of barriers to entry use [2]. 
not fit the picture given above. First, when the consumer contracts for a loan he is almost always buying something other than credit: a new car, a refrigerator, a washing machine and so on. He may shop around for the goods that he wishes to consume but when he finds what he wants, he will often take the credit that he can get most quickly subject only to the limitations of his paycheck. As George Katona has put it, "Regarding installment credit, most people are interested in something other than interest or carrying charges, namely the size of the monthly payments." [5, p. 240]

The second assumption, that of perfect knowledge, is also on somewhat shaky grounds. Even when the consumer is concerned with the cost of a loan, he may be so ill informed about credit as to be unable to find the most favorable type of loan. Several studies have found that few consumers know the rate of interest that they must pay on installment loans. In one early study, Juster and Shay [4] found that most consumers were unable to make an accurate estimation of interest rates that they were paying on loans. Other more recent studies conducted by the Survey Research Center [6, p. 150] and by the Federal Reserve Board [2] have shown results similar to those found by Juster and Shay. It was these findings, in part, that provided the incentive for the Truth in Lending Law.

The Truth in Lending Law which was enacted on July 1, 1969 required lenders to disclose the true effective rate of interest of loans which they offer. In a recent nationwide study of actual borrowers, [8] this author found that the effect of the Truth in Lending Law in making consumers aware of the cost of their loans was almost negligible. Before the Truth in Lending Law, borrowers could estimate the rate of interest they were paying on an automobile loan with an accuracy of approximately 45 percent. After the Truth in Lending Law accuracy went up to 53 percent. It appeared likely to this author that the reason why the Truth in Lending Law has not been effective is that most people do not have a sufficient understanding of what the rate of interest is and what it does, to cause then to want to remember it when it is disclosed to them. [7]

Yet, even if the Truth in Lending Law is successful in imparting the rate of interest to the consumer, it is not enough. As we have seen in our illustration of the perfect consumer, knowledge of the interest rate is a necessary but not sufficient condition for efficient operation in the consumer loan market. The consumer must also have enough of an 
understanding of the credit market to locate the lender who could best satisfy his needs.

\section{A STUDY OF CONSUMER KNOWLEDGE AND UNDERSTANDING OF CONSUMER CREDIT}

In order to learn more about the consumer's knowledge and understanding of credit and the credit market, a nationwide study was undertaken in the second half of 1971 by the Survey Research Center. A total of 1229 families which had previously been interviewed in person by the Survey Research Center were contacted by telephone and asked additional questions designed to ascertain their knowledge and attitudes towards consumer credit. Respondents were asked questions of varying sophistication regarding consumer credit in order to ascertain levels of information that they had of this matter and also to see whether and to what extent the level of knowledge was differentiated among the population by such important categories as income, age, education and experience with such credit.

\section{Sources of Credit}

Respondents were first asked to name the kinds of places that they could go in order to get financing to purchase a new refrigerator. Only 5 percent of respondents could think of no place where they could go to get such financing. Thirty-one percent of the population mentioned only one place while 41 percent of the population mentioned two places, 20 percent mentioned three places and 3 percent mentioned four or more kinds of places. Mentioned most frequently by far were banks which were named by nearly 80 percent of the total sample. Mentioned next most frequently were local department stores by 39 percent of the respondents and finance companies which were mentioned by 30 percent of the respondents. Relatively few people mentioned credit unions, local appliance dealers or nationwide chain stores.

With few exceptions, the types of places mentioned were not strongly related to any of the personal characteristics of the family. It might have been expected that the poorer families who are the most frequent customers of finance companies might name them most frequently but the data show this did not happen. To a slight extent, higher income families were more likely to mention banks as a source of financing and lower income families were less likely to mention the credit union than were the middle income families. 
Next, the families were asked which of the following would have the lowest finance charge for financing the purchase of a refrigerator over time: the bank, the credit union, the finance company or department store revolving credit. Forty-seven percent of the respondents said that the bank would have the lowest finance charge. This was followed by 33 percent of respondents who said that the credit union would have the lowest charge for credit. Nine percent of the population thought that the department store revolving would be the least expensive way to finance the purchase and only 1 percent chose the finance company as the lowest cost of finance.

Families were then asked which of the four sources of credit would have the highest finance charge. Over half of the families pointed to the finance company followed by some 28 percent of the population who said that department stores were the most expensive source of credit for this purpose. Responses to these questions, indicate that consumers have a general idea of the ranking of lenders in terms of cost.

\section{Interest Rate Estimates}

Having ascertained that most families were generally aware of the gross ranking of types of lenders, they were next questioned about the interest rates that would prevail on installment loans of various kinds. The first type of loan that families were querried about was the automobile loan. Here, a remarkable 36 percent of the respondents said that they had no idea what the rate of interest was on such a loan. An additional 12 percent of the population estimated that the rate was 6 percent or less, a very unlikely rate. Consequently, only half of the population was able to give a rate that might conceivably have been reasonable.

Table 1 shows that respondents who had a sizeable amount of debtthat is, at least $\$ 200$ of current installment debt, including automobile debt-were more likely to know what the rate of interest was on automobile loans than were other respondents.

Next, respondents were asked to estimate how much annual interest they would have to pay in order to finance a mortgage on a home. Here again, 34 percent of the respondents did not know (Table 2), while another 5 percent thought that the rate would be 6 percent or less, an unrealistically low estimate in the current market. In this instance, experience greatly improved the ability of the respondents to estimate the correct rate of interest. While 34 percent of the total population did not know the rate of interest that was charged on a mortgage loan, this 


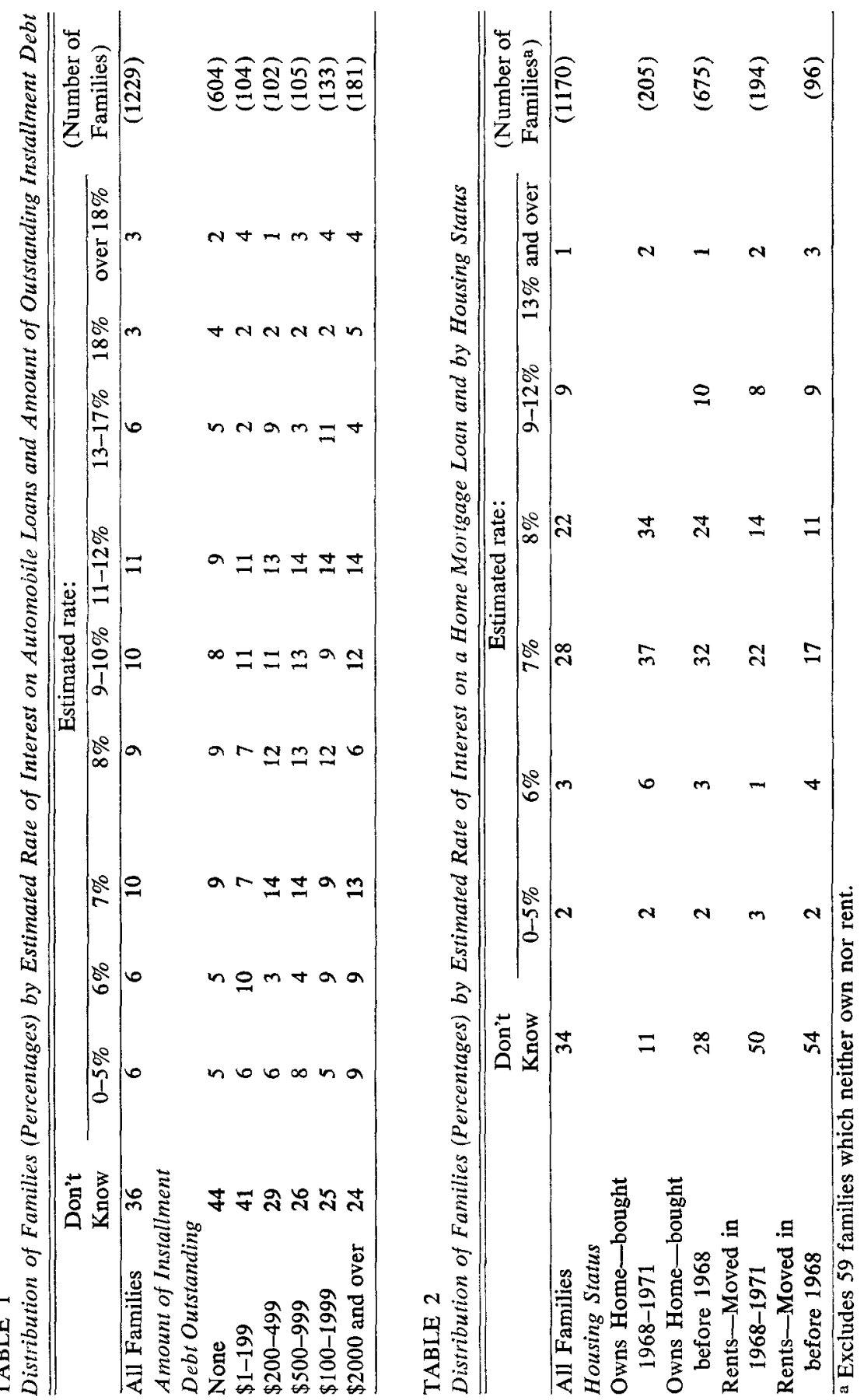


fell to only 11 percent of families who purchased a home within the previous year and 28 percent of other homeowning families. Among non-homeowning families, at least half had no idea of the current mortgage rate.

Respondents were next asked to estimate the percent finance rate charged for revolving credit in department stores. Here 44 percent of families said that they did not know while an additional 10 percent gave answers that were too low or too high. Only 27 percent of all respondents gave the answer as 18 percent, an answer which is correct for respondents in nearly every state. Even among families using store credit cards 36 percent said that they did not know the rate charged on these accounts (see Table 3 ).

\section{Accounting for Differences in Interest Rates}

In an attempt to gauge the knowledge and reasoning power of respondents in the area of consumer credit, they were asked why the rate of interest charged for a house mortgage was lower than that charged for a department store revolving credit. In this instance, 31 percent said that they did not know the reason. An additional 31 percent of the families said that the mortgage rate was lower because it was longer term-an answer that might be questioned by students of the money market but which is understandable enough when the administrative costs of the loan are added in. Twenty-four percent said that the mortgage was a more secure loan than the department store loan since the house served as very good collateral and an additional 24 percent gave the equally reasonable answer that department store credit included more service than did the mortgage. Four percent of the respondents said that the department store credit cost more because they made more profit than the bank.

\section{Knowledge of Expenses Connected with Granting of Credit}

The cost of credit may vary from lender to lender for many reasons including the amount of service included with the loan and the degree of risk that the lender is willing to take on with certain types of borrowers. For this reason, it is important for the prospective borrower to realize why lenders differ in terms of the cost of the loan in order to help guide him to select that type of loan which is best suited to his needs. The costs of credit may be broadly divided into three groups. First, there is the cost of money which is similar for most large lenders and may be said 


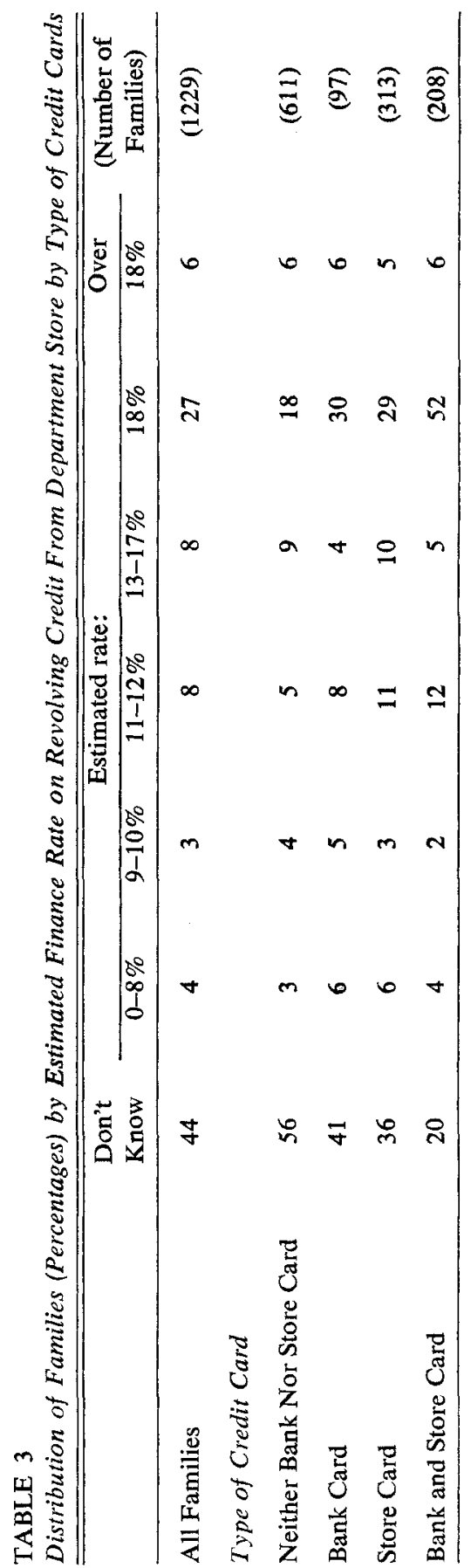


to approximate the prime rate of interest. Second, there is the risk of credit loss which is very small for lenders who lend only to the most reliable borrowers and is very high for lenders who lend money to much less reliable borrowers. Third, there is the cost of services connected with granting credit. This may be very low in the case of a bank installment loan where the customer makes a regular monthly payment without elaborate notification but it tends to be very high in the cases of credit cards or department store revolving credit where the cost of credit must cover high administrative costs for regular monthly billing, keeping track of numerous sales and purchases of goods including returns and the free credit service offered by most such plans which makes no charge for goods paid for within a certain period of time.

Since department store revolving credit included substantial charges in all three categories, respondents were asked whether they felt that the 18 percent charged by most department stores for credit was all profit or whether there were some expenses that must be covered. Only 7 percent of the families said that the finance charge was pure profit while an additional 7 percent said that it was mostly profit. Seventy percent of families admitted that there were some expenses and 5 percent said that most of the finance charge was necessary to cover expenses.

Respondents who did not think that the 18 percent was pure profit were asked what some of the expenses were. Seventy-four percent of respondents mentioned expenses which related to the administration of the credit. Twenty-two percent of respondents mentioned bad debt or credit loss as an expense connected with granting credit. However, only 3 percent of respondents spontaneously mentioned the cost of money which is used for credit.

When asked specifically about the lender's cost of money, ${ }^{3} 50$ percent of respondents said that they didn't know, while an additional 10 percent ventured incorrect answers.

\section{EVALUATING OVERALL CREDIT KNOWLEDGE}

In order to evaluate the causes or differences in consumer knowledge about consumer credit an index composed of responses to questions already discussed was formed. The respondent was given one point for correctly answering each of the following questions: In response to the

\footnotetext{
${ }^{3}$ The question was: "Most of us have some idea of what we would pay if we went out and borrowed some money. About what do you think a large company such as Sears or Wards pays if it has to borrow money to cover the cost of goods it is selling an credit?"
} 
TABLE 4

Multivariate Analysis of Knowledge of Consumer Credit

\begin{tabular}{|c|c|c|c|c|}
\hline & $\begin{array}{l}\text { Number } \\
\text { of Cases }\end{array}$ & $\begin{array}{l}\text { Mean } \\
\text { Score }\end{array}$ & $\begin{array}{l}\text { Unadjusted } \\
\text { Deviations }\end{array}$ & $\begin{array}{c}\text { Adjusted } \\
\text { Deviation }\end{array}$ \\
\hline \multicolumn{5}{|l|}{$\begin{array}{l}\text { Predictors } \\
\text { Family Income } \\
\left(\mathrm{B}^{2}=.092\right)\end{array}$} \\
\hline Under $\$ 3,000$ & 107 & 3.5 & -2.15 & -1.57 \\
\hline$\$ 3,000-4,999$ & 145 & 4.3 & -1.33 & -.87 \\
\hline$\$ 5,000-7,499$ & 178 & 5.2 & -.49 & -.34 \\
\hline$\$ 7,500-9,999$ & 197 & 5.8 & .19 & .18 \\
\hline$\$ 10,000-14,999$ & 312 & 6.4 & .78 & .62 \\
\hline$\$ 15,000-19,999$ & 141 & 6.9 & 1.28 & .94 \\
\hline$\$ 20,000-24,999$ & 85 & 6.8 & 1.20 & .60 \\
\hline$\$ 25,000$ and over & 64 & 6.7 & 1.07 & .39 \\
\hline \multicolumn{5}{|l|}{$\begin{array}{l}\text { Education of Head } \\
\left(\mathrm{B}^{2}=.087\right)\end{array}$} \\
\hline $0-5$ grades & 52 & 3.1 & -2.53 & -1.75 \\
\hline 6-8 grades & 199 & 4.7 & -.96 & -.51 \\
\hline 9-11 grades & 201 & 5.0 & -.60 & -.49 \\
\hline 12 grades & 229 & 5.8 & .11 & -.06 \\
\hline $\begin{array}{l}\text { High school and } \\
\text { non-college training }\end{array}$ & 150 & 6.0 & .40 & .09 \\
\hline College, no degree & 207 & 6.6 & .94 & .75 \\
\hline $\begin{array}{l}\text { College, Bachelor's } \\
\text { degree }\end{array}$ & 116 & 7.1 & 1.47 & 1.10 \\
\hline $\begin{array}{l}\text { College; advanced } \\
\text { degree }\end{array}$ & 67 & 7.3 & 1.70 & 1.14 \\
\hline \multicolumn{5}{|l|}{$\begin{array}{l}\text { Predictors } \\
\text { Size of Place } \\
\left(\mathrm{B}^{2}=.017\right)\end{array}$} \\
\hline $\begin{array}{c}\text { Central Cities of } 12 \\
\text { Largest SMSA's }\end{array}$ & 103 & 4.9 & -.74 & -.70 \\
\hline $\begin{array}{l}\text { Cities } 50,000 \text { and } \\
\text { over not including } \\
\text { Central Cities of } 12\end{array}$ & & & & \\
\hline Largest SMSA's & 254 & 5.6 & -.03 & -.09 \\
\hline $\begin{array}{l}\text { Urban Places 10,000 } \\
\quad 49,999\end{array}$ & 230 & 6.0 & .39 & .25 \\
\hline $\begin{array}{l}\text { Urban Places } 2,500 \\
9,999\end{array}$ & 266 & 5.7 & .10 & -.13 \\
\hline Rural, in an SMSA & 89 & 5.6 & -.05 & -.26 \\
\hline $\begin{array}{l}\text { Rural, not in } \\
\text { an SMSA }\end{array}$ & 287 & 5.6 & -.01 & .39 \\
\hline
\end{tabular}


TABLE 4 (continued)

\begin{tabular}{|c|c|c|c|c|}
\hline & $\begin{array}{l}\text { Number } \\
\text { of Cases }\end{array}$ & $\begin{array}{l}\text { Mean } \\
\text { Score }\end{array}$ & $\begin{array}{l}\text { Unadjusted } \\
\text { Deviations }\end{array}$ & $\begin{array}{c}\text { Adjusted } \\
\text { Deviations }\end{array}$ \\
\hline \multicolumn{5}{|l|}{$\begin{array}{l}\text { Housing Status } \\
\left(\mathrm{B}^{2}=.016\right)\end{array}$} \\
\hline Owns Home-Bo & & & & \\
\hline $\begin{array}{c}1968-1971 \\
\text { Owns Home-Bo }\end{array}$ & 205 & 6.7 & 1.07 & .40 \\
\hline Before 1968 & 675 & 5.8 & .14 & .16 \\
\hline $\begin{array}{c}\text { Rents-Moved in } \\
1968-1971\end{array}$ & 194 & 5.2 & -.43 & -.44 \\
\hline $\begin{array}{l}\text { Rents-Moved in } \\
\text { Before } 1968\end{array}$ & 96 & 4.6 & -1.07 & -.46 \\
\hline $\begin{array}{l}\text { Neither owns nor } \\
\text { rents }\end{array}$ & 45 & 5.3 & -.35 & .03 \\
\hline $\begin{array}{l}\text { Unrelated second } \\
\text { dweller }\end{array}$ & 14 & 4.3 & -1.39 & -.91 \\
\hline $\begin{array}{l}\text { Predictors } \\
\text { Age of Head } \\
\left(\mathrm{B}^{2}=.006\right)\end{array}$ & & & & \\
\hline Under 25 & 100 & 5.6 & -.06 & .06 \\
\hline $25-34$ & 234 & 6.2 & .60 & .14 \\
\hline $35-44$ & 238 & 6.2 & .52 & .03 \\
\hline $45-54$ & 256 & 5.9 & .28 & -.02 \\
\hline $55-64$ & 197 & 5.6 & -.08 & .15 \\
\hline $65-74$ & 145 & 4.6 & -1.07 & -.13 \\
\hline 75 and over & 59 & 3.4 & -2.26 & -.75 \\
\hline $\begin{array}{l}\text { Amount of Installm } \\
\text { Debt Outstanding } \\
\left(\mathrm{B}^{2}=.006\right)\end{array}$ & & & & \\
\hline None & 604 & 5.4 & -.27 & -.11 \\
\hline$\$ 1-99$ & 52 & 4.7 & -.92 & -.11 \\
\hline$\$ 100-199$ & 52 & 5.5 & -.17 & .17 \\
\hline$\$ 200-499$ & 102 & 6.0 & .36 & .45 \\
\hline$\$ 500-999$ & 105 & 6.1 & .47 & .19 \\
\hline$\$ 1,000-1,999$ & 133 & 5.9 & .25 & -.20 \\
\hline$\$ 2,000-2,999$ & 84 & 6.1 & .42 & .04 \\
\hline$\$ 3,000-4,999$ & 43 & 6.3 & .70 & -.06 \\
\hline$\$ 5,000$ and over & 54 & 6.4 & .76 & .37 \\
\hline
\end{tabular}

NOTE: Mean $=5.6$ (constant term) : the $R^{2}$ for the regression was 29 percent. Unadjusted deviations are univariate subgroups means expressed as deviations from the sample mean of 5.6. The adjusted deviations are dummy variable regression coefficients under the constraint that the weighted sum of the set of coefficients for the predictor equals zero. This yields the sample mean of the dependent variable as the constant term of the regression. The order of presentation of the variable is according to the size of the B coefficients which indicate the explanatory value of the variable. There were 1229 families in the regression analysis. 
lowest finance charge, the respondents' answer was scored as correct if he mentioned the bank or the credit union. For the highest finance charge he was given a point if he named either the department store credit or the finance company. For the percent rate of interest on an automobile, the response was scored as being correct if the rate was between 7 and 16 percent. A mortgage rate was accepted as being correct if the rate was between 5 and 9 percent. The store interest rate was accepted as being correct if it was between $10^{\prime}$ and 18 percent. In response to why mortgage interest rates were lower than those charged on department store revolving credits, up to 2 points were given for valid answers and in response to the question regarding expenses connected with the store's granting credit up to 3 points were given for naming the three correct categories. A last point was given if the respondent could correctly estimate the rate of interest that the store must pay for credit which was taken to be anywhere between 3 and 8 percent.

A Multiple Classification Analysis [1] type of multivariate analysis was run using the index of knowledge of consumer credit as the dependent variable and the following as independent variables; age of the head of the family, education of the head of the family, housing status of the family, total installment debt, size of the place in which the family lived and total income of the family. Persons with higher education and income were thought to be more likely to know about credit, older persons were thought to have more borrowing experience and be better informed, and persons who were currently financing a home or any other purchase were thought to have had impetus to learn about credit. Together, 29.24 percent of the total variance was explained by the variables (Table 4). Those which predicted most accurately were in order of importance, total family income and education of head, which together explained almost all of the variance.

Knowledge of credit is strongly and directly related to the income and the education of the family. In the case of education, mean scores rose monotonically in that each increased level of education was associated with a higher average index of accuracy (see Table 4). After adjustment is made for the effect of the other variables, respondents with less than 5 grades of schooling had scores averaging 1.75 points below the mean while respondents with advanced college degrees had scores averaging 1.14 points above the mean. In the case of income, mean accuracy rose strongly with increased levels except among the very highest income groups, that is over $\$ 20,000$ a year, where slight 
declines were noted, presumably as the result of less frequent use of installment credit by upper income individuals who can often afford to buy what they need without resorting to credit.

\section{SOME IMPLICATIONS}

What can we conclude about the results of this study? First, consumers generally seem to have a gross awareness of the ranking of different types of lenders in terms of cost. Second, a great proportion of consumers are unaware of current rates of interest being charged on such items as house mortgages, automobiles and department store revolving credit. Third, a large proportion of consumers do not appear to have an understanding of the credit market, of the reasons why different types of loans have different costs associated with them and the reasons why different lenders may be more or less costly. A fourth conclusion is that it appears that knowledge and understanding of the credit market is closely related to income and education of the family.

How do these findings contrast with the picture of the perfect consumer described above? First, we have seen from other evidence that most consumers do not in fact care as much about interest rates and the cost of credit as about other things, specifically the size of the monthly payment. Second, with the exception of those who are well educated and fairly affluent, most consumers have great gaps in their knowledge and understanding of the credit market. Therefore, it is not unrealistic to assume that many consumers, due to their lack of concern or knowledge, will accept the 18 percent rate charged by the department store or even the 36 percent rate charged by the finance companies when credit is needed.

There appear to be two ways to insure that the consumer does not consistenly overpay for credit. The first, which is less desirable from an economic standpoint, is to regulate the maximum allowable finance rates so that the consumer may not, in fact, agree to pay exorbitant rates. This provides protection for some consumers but it has the drawback of limiting the ability of other consumers, who, though probably small in number at this time, might be rational and well-informed and who also may not be very good credit risks, to seek credit. A second solution, which is far more equitable, is to attempt to inform and educate the consumer concerning the importance of knowledge about the credit market and also equip him with the basic facts and insights that he must know in order to function efficiently in that market. 


\section{SELECTED REFERENCES}

1. Andrews, Frank, James Morgan and John Sonquist, Multiple Classification Analysis, Ann Arbor: Institute for Social Research, 1969.

2. Board of Governors of the Federal Reserve System, Annual Report to Congress on Truth-in-Lending for the Year 1969, Washington: Board of Governors of the Federal Reserve System (multilithed).

3. Chapman, John M. and Robert P. Shay, Licensed Lending in New York, New York: Graduate School of Business, Columbia University, 1970.

4. Juster, F. Thomas and Robert P. Shay, Consumer Sensitivity to Finance Rates: An Empirical and Analytical Investigation, occasional paper No. 88, New York: National Bureau of Economic Research, 1964.

5. Katona, George, The Mass Consumption Society, New York: McGraw Hill, 1964.

6. ___ James N. Morgan, Jay Schmiedeskamp and John A. Sonquist, 1967 Survey of Consumer Finances, Ann Arbor: Institute for Social Research, 1968.

7. Mandell, Lewis, "The Changing Role of the American Consumer," Michigan Business Review, Vol. XXIV, No. 1, January 1972.

8. __ "Consumer Perception of Incurred Interest Rates: An Empirical Test of of the Efficacy of the Truth-in-Lending Law," The Journal of Finance, Vol. XXVI, No. 5, December 1971.

9. Ryan, W. J. L., Price Theory, London: Macmillan and Company Ltd., 1961.

10. Samuelson, Paul, Statement before the Committee of the Judiciary of the General Court of Massachusetts in support of the Uniform Consumer Credit Code, January 29, 1969. 